\title{
Production of Ethanol from Cocoa Pod Hydrolysate
}

\author{
Othman Abd Samah ${ }^{1}$, Salihan Sias ${ }^{2}$, Yeap Geok Hua ${ }^{2} \&$ Nurul Nadiah Hussin ${ }^{1}$ \\ ${ }^{1}$ Department of Biomedical Sciences, Kulliyyah (Faculty) of Science, \\ International Islamic University Malaysia \\ ${ }^{2}$ Department of Chemistry, University Putra Malaysia \\ Email: oas@iium.edu.my
}

\begin{abstract}
Cocoa pod (Theobroma cacao L.) hydrolysate was hydrolyzed into glucose using hydrochloric, sulphuric and nitric acids, respectively. The concentration of each acid was set at $0.25 \mathrm{M}, 0.50 \mathrm{M}, 0.75 \mathrm{M}, 1.00 \mathrm{M}$ and 1.25 $\mathrm{M}$. They were treated under two different temperatures and time at $75^{\circ} \mathrm{C}$ and $90^{\circ} \mathrm{C}$ for $2 \mathrm{~h}$ and $4 \mathrm{~h}$, respectively. The results showed that hydrolysis in $1.00 \mathrm{M}$ of hydrochloric acid at $75^{\circ} \mathrm{C}$ for $4 \mathrm{~h}$ had produced the highest glucose content of $30.7 \% \mathrm{w} / \mathrm{v}$ compared to all others acids treated under similar conditions. The pod's hydolysate was then fermented in batch culture using Saccharomyces cerevisiae for $48 \mathrm{~h}$ at $30^{\circ} \mathrm{C}$. A maximum ethanol production of $17.3 \% \mathrm{v} / \mathrm{v}$ was achieved after $26 \mathrm{~h}$ of fermentation time.
\end{abstract}

Keywords: cocoa pod; ethanol; fermentation; hydrolysate; S.cerevisiae.

\section{$1 \quad$ Introduction}

A substantial amount of work has been conducted to investigate the importance of bioconversion of wastes into useful products such as ethanol, acid and gas. Among the most widely used substrates for ethanol production are molasses of sugarcane and sugar beet [1]. However, many agricultural by-products or wastes may be converted into ethanol by biological process such as from orange peel, palm oil pith and cocoa pulp [2].

Cocoa pod was reported to contain about $43.9 \%$ to $45.2 \%$ carbohydrate [3], respectively. The high content of carbohydrate present in the pod is of considerable importance in manure manufacturing industry [4]. With the abundant supply of cocoa pods especially in cocoa growing countries such an industry could be a worthwhile undertaking for bioconversion of wastes into useful products. 


\section{$2 \quad$ Materials and Method}

\subsection{Moisture Content and Hydrolysis}

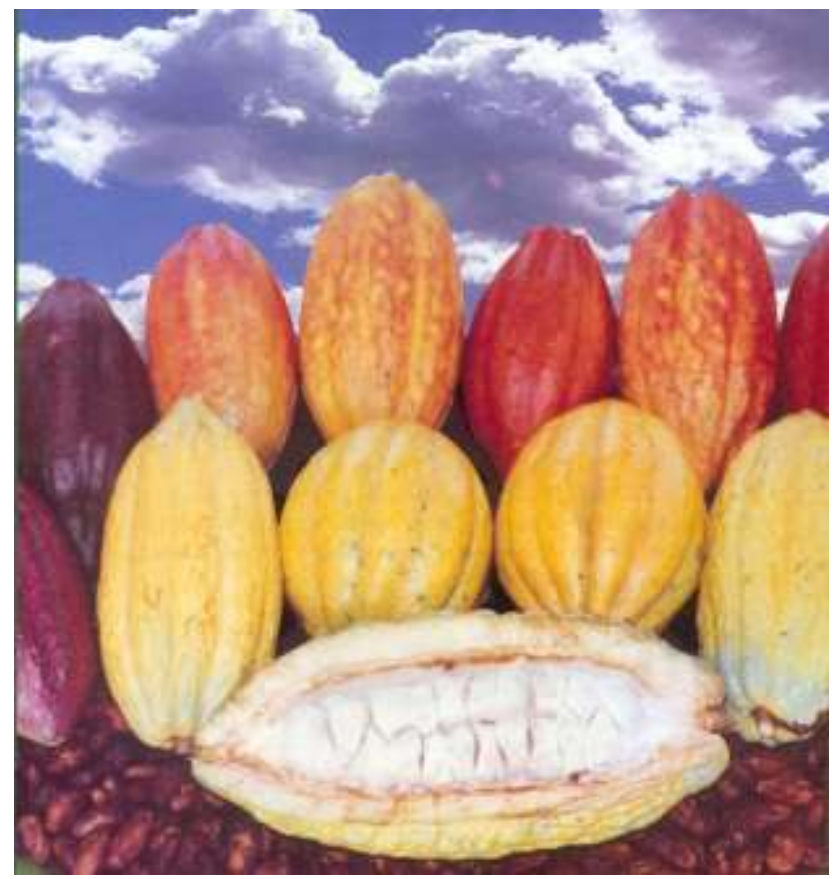

Figure 1 Cut open fruit showing typical thickness of a cocoa pod husk and cocoa seeds which are covered by white sweet flesh called mucilage. Husk size varies between hybrids.

Ripe cocoa pods (Figure 1), whose beans have been extracted, were cut into small pieces of 1-2 cm square. Samples were dried separately both under direct sunlight and in an oven at $70^{\circ} \mathrm{C}$ and $90^{\circ} \mathrm{C}$ until constant weight and were blended using National MX-495N blender. Six Grams of cocoa pod powder samples were vortex in duplicates in $\mathrm{HCl}, \mathrm{H}_{2} \mathrm{SO}_{4}$, and $\mathrm{HNO}_{3}$ of defined concentrations, respectively. Samples were refluxed at $75^{\circ} \mathrm{C}$ and $90^{\circ} \mathrm{C}$ each $2 \mathrm{~h}$ and $4 \mathrm{~h}$ before being filtered and neutralized with $2 \%$ of $\mathrm{NaOH}$ to separate their salt. Similar treatment was given to all other samples which were kept in a refrigerator at $0^{\circ} \mathrm{C}$ for further analysis.

\subsection{Glucose Determination}

For determination of glucose content, $5 \mu 1$ samples aliquot were injected into an HPLC (Model Shimadzu VP series) column $7.8 \mathrm{~mm}$ x $15 \mathrm{~cm}$ packed sulfonate whereby ligand exchange occurs between the counter ions of the packing materials. The chosen mobile phase is to complement the stationary phase so 
that the selected interactions are concentrated in the stationary phase. Thus, reverse phase having strong dispersive interactions would be used with a strongly mobile phase for example acetonitrile and water. In this study the system comprises acetonitrile: water $(75: 25 \mathrm{v} / \mathrm{v})$, flow rate $2.0 \mathrm{ml} \cdot \mathrm{min}^{-1}$ and oven temperature which was programmed at $25^{\circ} \mathrm{C}$. Glucose was quantified from peak areas by reference to a pure standard glucose (Merk, Germany).

\subsection{Fermentation}

$850 \mathrm{ml}$ cocoa pod hydrolysate was sterilized in 1 litre LH fermentor (L.H. Engineering Co, Stoke Poges, Bucks, U.K) by autoclaving at $121^{\circ} \mathrm{C}$ for $15 \mathrm{~min}$. Twenty milliliters of fresh culture yeast (Saccharomyces cerevisiae) was inoculated aseptically into the fermentor with continuously stirring at $500 \mathrm{rev}$. $\mathrm{min}^{-1}$. Samples were taken at regular intervals for purity test by microscopic examination and for determination of culture optical density. Absorbance was read against uninoculated media in $3 \mathrm{ml}$ cuvet at $600 \mathrm{~nm}$ using spectrophotometer (Spectronic 20, Milton Roy Co, USA).

\subsection{Ethanol Determination}

Culture samples were centrifuged (Damon IEC centrifuge, Model B-20, USA) at $10,000 \mathrm{x}$ g for $10 \mathrm{~min}$ at $4^{\circ} \mathrm{C}$. The supernatant obtained was filtered through a Millipore filter $(0.45 \mu \mathrm{m}$ pore size membrane filter) and $5 \mu \mathrm{l}$ samples were injected in replicates in HPLC (Model Shimadzu series) Waters FFJA column $(1.9 \times 300 \mathrm{~mm})$ with a mobile phase of acetonitrile and water $(75: 25 \mathrm{v} / \mathrm{v})$, flow rate $1.5 \mathrm{ml} \mathrm{min}{ }^{-1}$ and oven temperature at $25^{\circ} \mathrm{C}$. Ethanol was quantified from peak areas by reference to a standard of pure ethanol (Hamburg Chemicals, Germany).

\section{$3 \quad$ Results and Discussion}

Probably the technique for drying by blasting hot air at any given fixed temperature either at $70^{\circ} \mathrm{C}$ or $90^{\circ} \mathrm{C}$ in an oven is more efficient in determining the moisture content for any large scale industry since it saves time. Table 1 shows a slight variation of moisture content between oven and sunlight techniques. According to Chin and Roberts [5], the initial moisture content is important as it has some effects on the pods viability. Insufficient dryness of the cocoa pods would of course encourage fungus to grow resulting the pods might lose some of its sugars.

Concentrated $\mathrm{HCL}$ and $\mathrm{H}_{2} \mathrm{SO}_{4}$ acids are capable of swelling and dissolving cellulose or starch. As shown in Figure 2, hydrolysis with 1.00 M of HCL for 4 $\mathrm{h}$ at $75^{\circ} \mathrm{C}$ gave a maximum yield of $30.7 \% \mathrm{w} / \mathrm{v}$ glucose. According to Robinson 
[6], the current technology could not support if strong glucose solutions are required for fermentation with weak acid solutions. Most of the industry today uses sulfuric acid rather than preferred hydrochloric acid. Although HCL is more expensive, it gives faster reaction and it is indeed easier to control in the microwave reactor. Moreover, $\mathrm{H}_{2} \mathrm{SO}_{4}$ tends to produce more decomposition products. Other acids, such as phosphoric or acetic prove to be too weak to effect the reactions desired at reasonable temperatures and pressures and they do not give good conversions.

Table 1 Moisture content of cocoa pods (without beans).

\begin{tabular}{cccccc}
\hline \multicolumn{2}{c}{ Initial Weight (gm) } & \multicolumn{2}{c}{ Final Weight(gm) } & \multicolumn{2}{c}{ \% Moisture Content } \\
Oven & Sunlight & Oven & Sunlight & Sunlight & Oven \\
\hline 243.20 & 159.50 & 206.90 & 134.00 & 85 & 84 \\
300.00 & 258.70 & 264.00 & 206.90 & 88 & 80 \\
295.10 & 200.00 & 244.90 & 170.00 & 83 & 85 \\
152.60 & 224.60 & 129.70 & 195.40 & 85 & 87 \\
Average: & & & & & \\
247.70 & 210.70 & 211.40 & 176.60 & 85 & 84 \\
\hline
\end{tabular}

It appears that the glucose percentage (Figures $2 \& 3$ ) increased as the concentration of acids becoming greater but decreased after reaching a maximum yield. This implies that the hydrolysis is a concentration dependant which shows that by increasing acid concentrations it does not necessarily enhance the hydrolysis performance. However, when the temperature was increased from $75^{\circ} \mathrm{C}$ to $90^{\circ} \mathrm{C}$, the glucose production had decreased. Perhaps, by increasing the temperature from $70^{\circ} \mathrm{C}$ to $90^{\circ} \mathrm{C}$, it could act as an inhibitor of achieving higher yield of glucose. These findings are in agreement with those reported by Riera et al. [7], which stated that the yield of furfural via hydrolysis were a function of reaction temperature, particle size liquid / solid ratio and acid concentrations. The fermentation rate at high temperatures will be low because high temperatures are lethal to viable yeast and would certainly damage its cellular components. Enzymes move too fast and denature at high temperatures [8]. According to Sener et al. [9], cool temperatures prolong the lag phase of fermentation which may slow down the rate of fermentation. Excessively high temperatures may disrupt enzyme and membrane functions, resulting in stuck fermentation and eventually decrease the production of glucose. 


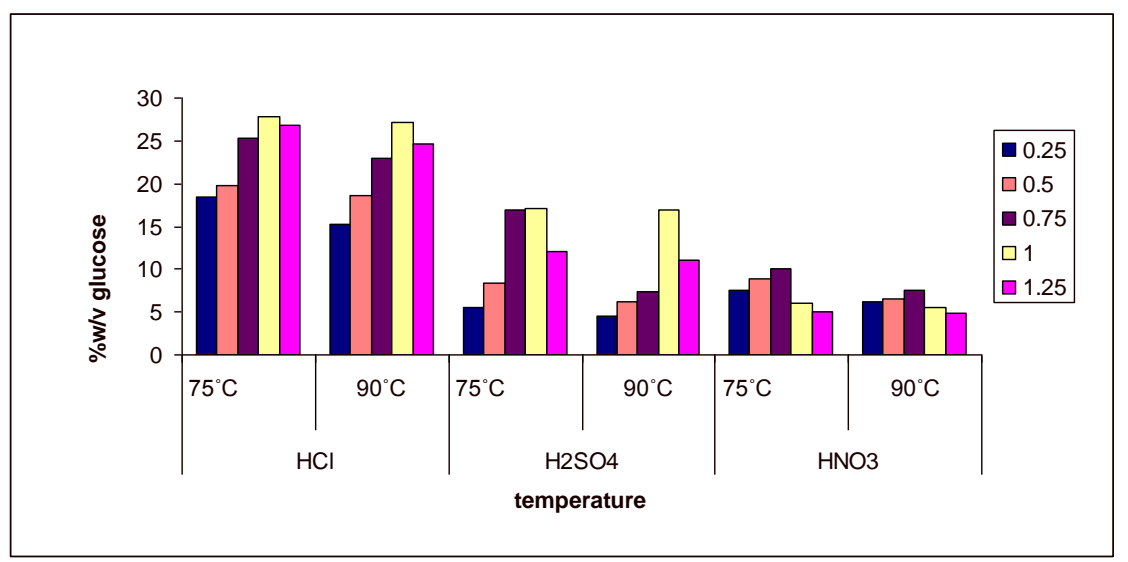

Figure 2 Percentages of glucose obtained by after 2 hours hydrolysis at $75^{\circ} \mathrm{C}$ and $90^{\circ} \mathrm{C}$ in various acid concentrations.

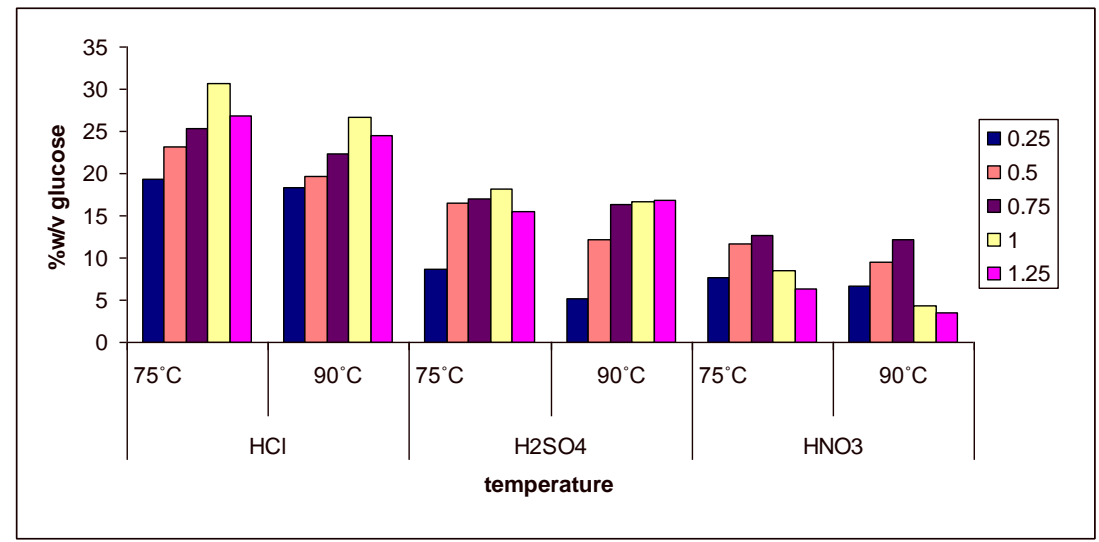

Figure 3 Percentages of glucose obtained after 4 hours hydrolysis at $75^{\circ} \mathrm{C}$ and $90^{\circ} \mathrm{C}$ in various acid concentrations.

The temperature of fermentation can affect the development of different Saccharomyces strains. The yield of ethanol and other fermentation by products are also related to temperature. Temperature can affect the sensitivity of yeasts to alcohol concentration, growth rate, rate of fermentation, viability, length of lag phase, enzyme and membrane function. Many yeast strains behave differently in their response towards temperature, therefore their common optimum temperature could not be easily established [9].

During fermentation process, yeast converts simple sugars to ethanol by Embden Meyerhof-Parnas pathway to pyruvic acid, which is then decarboxylated to acetaldehyde by pyruvic carboxylase. The acetaldehyde is reduced to ethanol by alcohol dehydrogenase. Theoretically, it is known that the 
yield of ethanol from the fermentation of $1 \mathrm{~kg}$ of glucose would produce 0.51 $\mathrm{kg}$ of ethanol at specific gravity of 0.79 [10]. Thus, $1 \% \mathrm{w} / \mathrm{v}$ of glucose could produce $0.647 \%$ v/v ethanol.

Therefore, the percentage of ethanol yield $=$

Maximum ethanol produced x 100

Theoretical ethanol yield (i.e. \% of initial sugar x 0.647 )

It may be assumed that $45 \mathrm{~kg}$ of fermentable sugar could yield $18-23 \mathrm{~kg}$ of ethanol [11]. In the present study, the initial glucose used was $30.7 \% \mathrm{w} / \mathrm{v}$. Therefore, theoretically it should yield $19.9 \%$ of ethanol. However, the results showed that the maximum ethanol production of $17.3 \% \mathrm{v} / \mathrm{v}$, so called the fermentation efficiency, occurred after approximately 26 hours of fermentation time at an optical density of 0.75 at $600 \mathrm{~nm}$ (Figures 4 and 5).

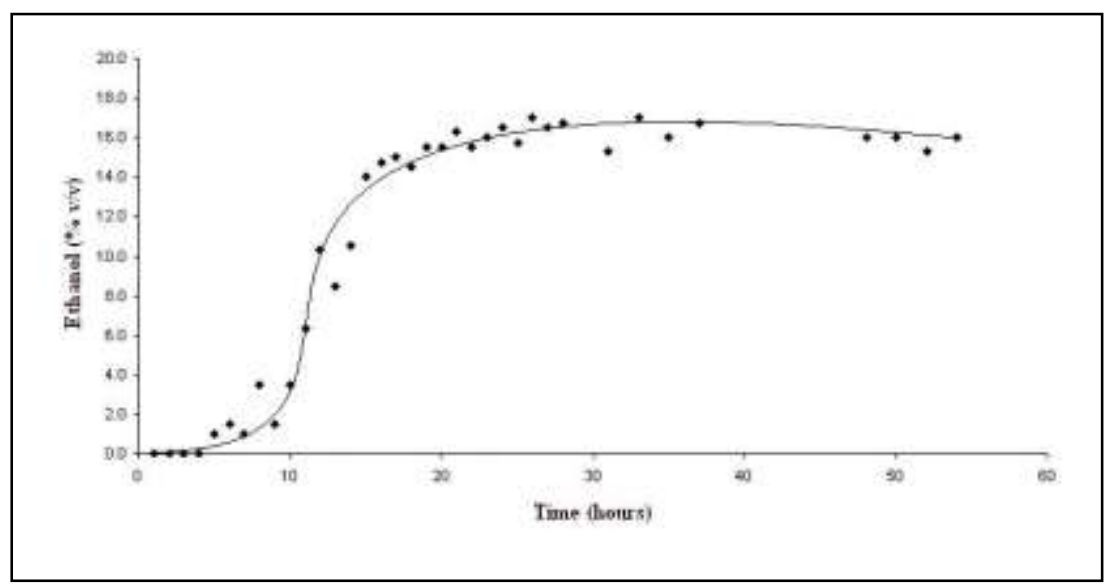

Figure 4 Percentage of ethanol production versus incubation time of $S$. cerevisiae grown in batch culture.

According to Deshpande [12], in batch fermentation, the manufacturing industry shall be facing low fermentation efficiency problems. To solve these problems, continuous fermentation is highly recommended to use $S$. cerevisiae in an immobilized cell reactor thus optimizing the performance of fermentation process $[12,13]$.

Immobilization via cell entrapment in a supporting matrix can introduce diffusional limitation that can be circumvented by employing dynamic cell immobilization produced by membrane assisted microfiltration. The use of microfiltration to retain cells within the fermenter eliminates the need for a 
support matrix, and therefore allows relatively unimpeded nutrient and oxygen transport. Thus, cell retention by microfiltration can give faster fermentation rates than cell entrapment and allows the use of aeration. Cell retention has been used to obtain extremely high volumetric fermentation rates with little effect on cell productivity in anaerobic glucose fermentation with S. cerevisiae [14].

Moreover, by providing an ecosystem that selected for the successional growth of yeasts also can improve the production of ethanol [15]. For growth and multiplication, yeast requires utilizable organic carbon (sugars), nitrogen source, various organic and inorganic trace growth factors. Proper nutrition, as for any living organism, is the key to making yeast thrive and obtain optimum performance [12].

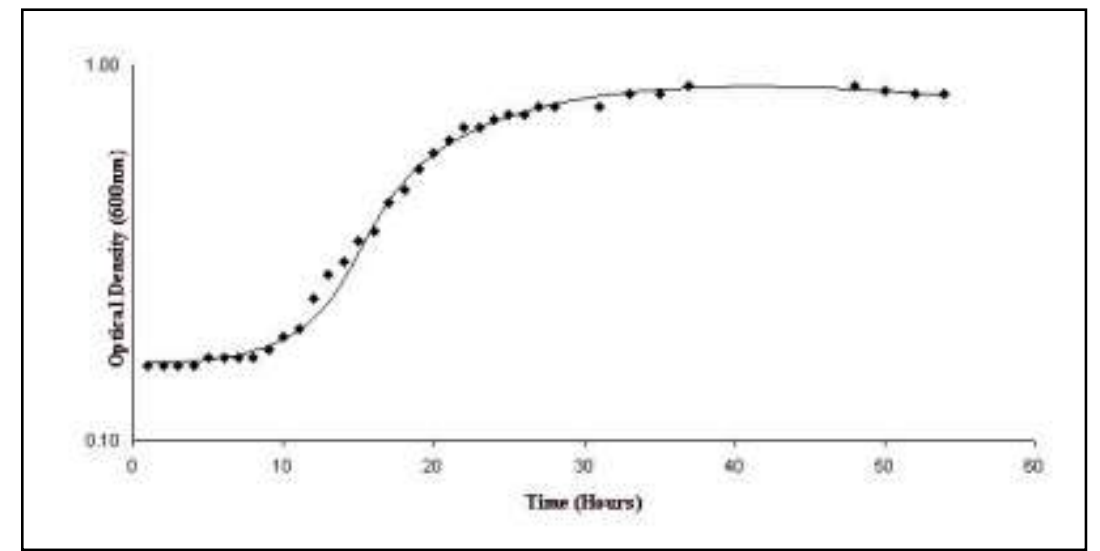

Figure 5 Optical density of $S$. cerevisiae grown in batch culture at various fermentation time.

\section{Conclusion}

The results of this study show that the rate of alcohol production through fermentation of cocoa pod hydrolysate by local strain yeast (S. cerevisiae) achieved a maximum ethanol production of $17.3 \% \mathrm{v} / \mathrm{v}$ after $26 \mathrm{~h}$ of fermentation time. The findings of this work suggest that alcohol can be produced from cocoa pod.

\section{Acknowledgements}

This investigation was financially supported by IRPA. The authors would like to thank Mr. Onn Ahmad, Department of Biochemistry and Microbiology, UPM for technical assistance. 


\section{References}

[1] Rose, D., Yeast Molasses Alcohol, Process Biochemistry, 12, 10-12, 1976.

[2] Othman A.S., Abd Rashid, A.R. \& Mohd Ismail A.K., Utilization of Some Agrowastes for Alcohol Production, Journal of Industrial Technology, 2(1), 45-49, 1992.

[3] Davendra, C., The Feeding Value of by-Product from Cocoa and Coconuts in Diets for Farm Livestock, in Proceeding of the International Conferencence on Cocoa and Coconuts, Kuala Lumpur, pp. 457-471, 1980.

[4] Jalaluddin, J., Bio and Organic Fertilizers Country Report, Expert Consultation of the Asian Network on Bio and Organic Fertilizers, FAO, Bangkok. Thailand, 1988.

[5] Chin, H.F. \& Robert, E.H., Germination in Recalcitrant Crop Seeds, Kuala Lumpur: Tropical Press Sdn. Bhd., 1980.

[6] Robinson, M.J., Method of Digesting Cellulose to Glucose Using Salts and Microwave (Muwave) Energy, US Patent Application Publication, pp. 1-22, 2010.

[7] Riera, F.A., Avarez, R. \& Coca, J., Production of Furfural by Acid Hydrolysis of Corncob, Journal of Chemical Technology \& Biotechnology, 52(2), 149-154, 1999.

[8] Tsao, G.T., Ethanol and Chemical from Cellulosics, Food Technology Centre, Taipei, ASPAS Publisher, 1984.

[9] Sener, A., Canbas, A. \& Unal, M.U., The Effect of Fermentation Temperature on the Growth Kinetics of Wine Yeast Species, Turkish Journal of Agriculture and Forestry, 31, 349-354, 2007.

[10] Adams, M.R. \& Flynn, G., Fermentation Ethanol: An Industrial Profile. Tropical Products Institute, London, pp. 1-19, 1982.

[11] Rees, D.A., The Shapes of Molecules Carbohydrate Polymers, Oliver and Boyd Ltd., London, 1967.

[12] Deshpande, G.B., Overview of Continuos Alcohol Fermentation and Multipressure Distillation Technology, in Proceedings of the South African Sugar Technology Association, 76, 574-581, 2002.

[13] Najafpour, G., Younesi, H. \& Syahidah, Ku Ismail K., Ethanol Fermentation in an Immobilized Cell Reactor using Saccharomyces cerevisiae, Bioresource Technology, 92(3), 251-60, 2004.

[14] Alexander M.A., Chapman T.W. \& Jeffries, T.W., Continuous Ethanol Production from D-Xylose by Candida shehatae, Biotechnology and Bioengineering, 30, 685-691, 1987.

[15] Ardhana, M.M. \& Fleet, G.H., The Microbial Ecology of Cocoa Bean Fermentations in Indonesia, International Journal of Food Microbiology, 86, 87-99, 2003. 